Reviews

Many of the essays told compelling stories of the histories and challenges of adjusting to changes to place and space for different ethnic groups. Airriess' imagery of the Vietnamese refugee community in New Orleans vividly showed how their churches, retail shops and vegetable gardens serve as cultural reminders of the traditional practices and values that were left behind when they fled Vietnam and aid their adaptation to a foreign social and physical environment. Hannah's descriptions of how the Oglala used their mobility and the terrain of the western planes to resist dominance and oppression was compelling, but ultimately, mobility did not equal freedom for the Oglala Lakota. The macro level essays, especially Roseman's ethnic mapping and Deskins and Bettinger's description of Black and White residential and economic segregation provide interesting glimpsing into the future of America - it may becoming more multi-racial and ethnic and separate.

In other essays, the links between race and place were not always well defined. In Koletty's description of Samoan immigrants, the author never acknowledges that many of the methods of continuing ties to a homeland is typical of most migrants - not unique to Samoans as an ethnic group. Smith's ironic investigation of how the migration of "Anglos" altered the cultural traditions of the Spanish people of the region fails to mention of how this Spanish settlement may have disrupted the Native Americans and Mexicans indigenous to the area. In addition, the vagueness of the editors' definitions of the macro, meso and micro scale made it difficult to categorize the essays within this framework. It was assumed that the essays were arranged in that sequence.

Overall, this volume provides well written essays that used the main themes to relate how very different ethnic or racial populations attempt to maintain or recreate their identities in terrains that are changing, or are changed because of relocation. The essays describe a variety of interactions between race, space and place within the social-spatial topics of immigration, landscapes, housing and social connections. These interactions illustrate the complexity of examining relationships to place. I recommend this volume to all social scientists who strive to understand such complexities.

\title{
After Revolution: Mapping Gender and Cultural Politics in Neoliberal Nicaragua , by Florence E. Babb. (2000), Austin: University of Texas Press, 2001.
}

\section{Reviewed by Lorraine Bayard de Volo, University of Kansas}

International attention to Nicaragua has waned considerably since the Contra War ended and the Sandinistas lost the elections in 1990. Yet in demonstrating how the long struggle for democracy and economic justice is being waged after the revolution, Babb demonstrates why this country deserves our continued attention. Through narratives that supply multiple windows into the lives of Nicaragua's urban poor and working class, we witness both the despair wrought by neoliberalism and political corruption and the seeds of hope that continue to be sown through an emerging civil society and network of social movements.

Four facets of this book give us valuable insights into both the political economy and cultural politics of contemporary urban Nicaragua: gender, cooperatives, urban studies (Managua), and post-revolutionary capitalist culture. By following the lives of women and men in a Managua barrio and in several cooperatives during her fieldwork in Nicaragua between 1989 and 2000, Babb noted a connection that she had not initially expected: the relation between changes in the political economy and developments in social activism (especially feminist groups) (26). The post-1990 expansion of social movements, she argues, is not simply the result of democratization or a continuation of FSLN politics, though these play a role. Specifically, she contends that expanding social activism is due to challenges to hierarchical Sandinista party politics, opposition to neoliberalism, and the continued cultural politics of activism under regimes that tolerate a degree of dissent $(27,173)$.

Much to her credit, Babb frames her research in terms of urban studies. Unlike some commentators on Nicaraguan culture and politics, she purposefully centers her research in Managua rather than doing her research primarily in Managua and yet making claims that broadly encompass Nicaragua as a whole. More specifically, she embraces the city itself as a central subject of her research, discussing "how neoliberalism has altered the urban landscape in ways that are inflected by gender" (49).

Throughout the book, Babb "maps" gender, asking, for example, "What has neoliberalism meant for Managua, and how are gender and class differences manifest in the present urban context?" (57). She notes that with 
Reviews

the post-1990 budget cuts, along with a reinvigorated conservative political culture, women were pressured to leave formal sector jobs to return home, even when they still somehow had to provide for their families (57). "Erasures of women's spaces in the city were increasingly common as opportunities to participate in the wider economy began to shrink" (58). In the meantime, "their presence in informal trades (often hidden from view) and even begging (in public) was greater" (58). Particularly disturbing is women's and girls' increased involvement in prostitution since 1990.

Although she examines women's household and unpaid work, she also insists that women's paid and unpaid work are interconnected in important ways (108). Thus, while the research done on women's unpaid labor has advanced our thinking about economic development, such research should not come at the expense of our understanding of women's experiences of neoliberalism in terms of their paid work. Much of her ethnographic research, accordingly, was devoted to producing in-depth, micro-level studies of working women and how their experiences changed over time in relation to changes in the political economy (117). In particular, Babb charts women's work in urban cooperatives, noting also the neoliberal conversion of many cooperatives into microenterprises. She provides four rich case studies that reveal both the variety of women's experiences in cooperatives as well as the crushing affect of economic crisis. As production and sales have slowed, women generally increased their efforts, working longer hours in search of less expensive materials, acquiring new skills, and finding new markets for their products (148). Yet the strain produced by economic crisis, increased competition, and the disappearance of state supports has driven many cooperatives and small businesses out of business and has also seriously impacted women's abilities to carry out family responsibilities. Since roughly half of urban Nicaraguan households are headed by women and women make up 44 percent of the economically active population, economic policies which do not take gender into account will have particularly dire effects on these women and their children (148-9). In this gloomy scenario, Babb offers a ray of hope. Nicaragua's most vulnerable social groups, according to Babb, are uniquely qualified to confront neoliberalism due to the Sandinista emphasis on social mobilization in the prior decade: "The decade of broad participation left a legacy of expectations that has been challenged but not eliminated since 1990" (148).

Still, many cooperatives have disbanded since 1990. In other cases, family pressures (child care problems and husband's attitudes) as well as NGO encouragement for cooperatives to refashion themselves as microenterprises have promoted individualism in place of a Sandinista model of cooperation $(162,165)$. This transition from cooperatives to microenterprises is a rich site of study that can mined more deeply by future research. Babb's work is unique, and thus the literature has just scratched the surface of this transition.

There is also an interesting chapter comparing narratives of development, in which Babb explores the discourse of neo-liberal and Sandinista policymakers. In addition to the common tropes of neoliberals, she also found a disturbing conservative sub-theme regarding women - for example, the notion that female state employees leaving public sector jobs as a result of structural adjustment were mainly "housewives" who now could return to their families (185). Interestingly, despite certain differences, the neoliberal and Sandinista discourses agree that the economic solution requires some measure of structural adjustment and that "the workers themselves embody the potential of the nation to forge ahead and "develop"' (187). Elite critics of neoliberalism in Nicaragua have not proposed alternatives so much as proposed more gradual measures. A starker contrast to neoliberal discourse is to be found in the urban workers interviewed by Babb. Through these interactions, Babb noted a persistent appeal to the body and personhood with regards to economic shifts, revealing a resistant and potentially revolutionary consciousness (190-1). Babb eloquently sums up these contrasting discourses: "What appears to be notably different is the elite's notion of the harsh medicine that is needed to heal the nation and working-class and poor people's imagery of the bodily consequences of both the economic crisis and the medicine that is being administered to deal with it" (196-7).

Also impressive is the manner in which Babb has developed new footholds for our understanding of the sometimes frightening pace of capitalist development in Managua and its visible cultural markers. She does this with great attention to detail, including treatments of such "events" as the building of the new cathedral, the opening of a new McDonalds, and the "mallification" of Managua (complete with food courts and escalators!), framing many of these changes in terms of the emerging national identity centered on consumption (243). Through these examples, we come to see how "As Managua is remade, it is increasingly the space of an elite" (67).

Babb concludes that women's strategies in confronting the economic crisis may not be sufficient to withstand the impact of structural adjustment, suggesting that "more thorough-going structural transformation may be needed once again in Nicaragua" (108). But the tone of this book is ultimately hopeful. Babb documents the grim results of neoliberal economic policies, but she also highlights the new autonomous forms of activism that challenge both this neoliberalism and the undemocratic trends within Sandinismo. Never denying the policy mistakes, undemocratic tendencies, and instances of corruption of the Sandinista revolution, she insists that it also "made social subjects of 
Reviews

those who before had little voice or political influence" (210). Fortunately, Babb carried out her research despite the ebbing international interest and was able to note sites of resistance not only in relation to economic policy but also to gender power relations, lesbian and gay issues, and peace.

After Revolution is essential reading for those interested in women and work, the local effects of neoliberalism, urban studies in lesser developed countries, Latin American cultural politics, and collective action. For those unfamiliar with post-1990 Nicaragua, this book will provide an excellent overview of the vast, rapid changes the country has gone through while also making important connections to the Sandinista past. For those studying women's work, Babb makes an important case for the interconnectedness of women's paid and unpaid work. For those interested in economic policy, this book shares insights into poor urban women's local-level experiences of large economic shifts - insights that can only be originally derived from the long-term, careful ethnographic work of a committed scholar.

\section{Marx and the Postmodernism Debates: An Agenda for Critical Theory by Lorraine Y. Landry. London: Praeger Publishers (2000), xiii+232pp.}

\section{Reviewed by Douglas J. Cremer, Department of Natural and Social Sciences, Woodbury University, Burbank, CA.}

Lorraine Landry has confidently entered a field that has drawn much attention among philosophers: the debate between Jürgen Habermas on the one hand and Jacques Derrida, Michel Foucault, and Jean-François Lyotard on the other. Rather than seeing this intersection as one between a rationalist modernism and an irrationalist postmodernism, Landry seeks to create what she calls a "fruitful tension" between these two warring camps by reconceptualizing the debate through the work of Karl Marx. The connection between Marx and Habermas is clear. Habermas, as the heir to Theodor Adorno and Max Horkheimer, is recognized as the latest German philosopher to build off of Marx' work. That a rapprochement between these two positions might be accomplished through the work of Marx has also been hinted at in Derrida's later works as well as in the widely know early Marxian roots of Lyotard and Foucault. Landry makes profitable use of a wide variety of well-known commentators on the debates, among them Seyla Benhabib, Matei Calinescu, Mike Featherstone, Douglas Kellner, Andreas Huyssen, Alex Callinicos, Christopher Norris, Thomas McCarthy, Peter Dews, and David Rasmussen. Due to the wide range of material covered and the clarity of writing, Marx and the Postmodernism Debates is a welcome addition to this highly developed, intellectually rich and philosophically challenging literature, doing an admirable job of summarizing the major issues and developing a new approach that keeps the book from being another rehash of a now lengthy debate.

By explicitly reintroducing Marx to the debates, Landry hopes to show the relevancy of postmodern thought for social change and contemporary politics, making it part of the tradition of ideology critiques begun by Marx. Yet before undertaking this project, Landry goes back to the work of Immanuel Kant, who is as important as Marx in her overall analysis. It is in Kant's work that Landry sees the fully developed form of modernity: individualist, instrumental, mechanical, methodological, and manipulative. Yet this modernity, she argues, was from its origins tied to and complicated by the earlier existing organic conception of the world as well as the emerging romantic view. Landry makes the argument that there are thus as many modernisms as there are postmodernisms, as many different forms of Enlightenment rationalism as there are postmodern critiques. Her analysis of aesthetic modernism, as a variant within modern thought that was intensely critical of the rationalist strain of modernism, is well argued. It is one of the cornerstones of her effort to show how the paradoxes and complexities of postmodernity were embedded in the paradoxes and complexities of modernity. One of the strengths of this book is the clear way Landry lays out these important issues.

The apparent conflict between modernity and postmodernity is repositioned by Landry as a "fruitful tension," a phrase she admits is a bit trite. Her stated methodology is to take the positions of Habermas, Derrida, Foucault and Lyotard each on its own terms and as empathetically as possible, referring to similarities and differences, avoiding easy syntheses and polemics, and seeking a viable theory and politics from each. She initially addresses Habermas' 